\title{
A economia política hoje (e outros assuntos)
}

Carta de Leda Paulani ${ }^{1}$

Resumo: a presente carta inicia com algumas problematizações dos fundamentos filosóficos mais contemporâneos à luz da perspectiva crítica do materialismo marxiano para passar às considerações sobre a emergência e o desenvolvimento da chamada "revolução marginalista" no âmbito econômico, da teoria keynesiana e, posteriormente, da chamada teoria das expectativas racionais, levantando os problemas de cada uma delas a partir da perspectiva marxista.

Palavras-chave: Economia política; Pensamento Econômico; Capitalismo; História.

${ }^{1}$ Professora titular sênior do Departamento de Economia da FEA-USP e da PósGraduação em Economia do IPE-USP. Pesquisadora e professora visitante da UFABC. Pesquisadora do CNPq (nível 1D). 
São Paulo, 26 de agosto de 2018. ${ }^{2}$

\section{Caro Marx,}

Desde que você partiu para essa sua longa viagem, já se vão lá 135 anos, muita coisa mudou nesse mundo velho de guerra. Se você baixasse por aqui agora não reconheceria quase nada. $\mathrm{O}$ seu mundo silencioso, de lampiões, carruagens e lama nas ruas, mesmo no centro desenvolvido do sistema capitalista - na Londres em que você vivia, foi substituído por um outro, brilhante, cheio de luz, muito veloz, estridente e muito barulhento. A energia elétrica tomou conta de tudo e virou bem de primeiríssima necessidade; quase nada se faz sem ela. $\mathrm{O}$ motor a explosão substituiu a tração animal nos veículos que transportam pessoas e coisas e hoje esses veículos são programados para andarem até mesmo sem condutor (que agora se chama motorista). Ao invés de 20 dias trancafiado num navio para atravessar o Atlântico, hoje se vai de Londres a Nova Iorque em apenas 8 horas e voando! Os trabalhadores, os operários sobre os ombros dos quais você colocou uma enorme responsabilidade histórica, são hoje cada vez mais substituídos por robôs, máquinas em formato de gente que executam os movimentos necessários à produção industrial com precisão e rapidez e sem se cansarem, sem ficarem doentes, sem exigirem descanso semanal e jornada de 8 horas. O telefone, que mal tinha sido inventado e dependia de intermediários em suas centrais telefônicas para funcionarem, hoje andam colados às pessoas e se movimentam junto com elas. Com uma pecinha que cabe na palma da mão, você fala hoje, de qualquer parte do mundo, a qualquer momento, com qualquer pessoa, em qualquer outra parte do mundo (e pode até mesmo vê-la). A mágica que está por trás desses pequenos objetos (que chamamos "celular") criou algo ainda mais incrível: uma inteligência

\footnotetext{
${ }^{2}$ Nas notas de rodapé, conversarei com os leitores da carta.
} 
artificial que, segundo alguns profetas, pode vir a afrontar a própria inteligência humana. ${ }^{3} \mathrm{E}$, para terminar esta lista totalmente incompleta de inacreditáveis transformações, a referida mágica criou também um "mundo virtual", um mundo paralelo, que parece desafiar a máxima de Hegel de que o possível, como puro possível é impossível, ${ }^{4}$ pois ele é a possibilidade encarnada, objetivada, a possibilidade existente. Enfim, este parece de fato outro mundo, que não tem rigorosamente nada que ver com aquele que você conheceu.

Mas sabe o mais interessante? Ele só está hoje assim, tão aparentemente diferente, porque esse mundo "moderno", fruto de profundas revoluções que ocorreram no Ocidente, nunca deixou de ser aquilo que você descobriu que ele era: um mundo tocado por uma lógica inabalável, um movimento sem fim de acumulação de riqueza abstrata, que tudo vai arrastando e transformando. É essa lógica poderosa, por isso, a causa maior de todas as enormes mudanças estampadas na paisagem social e humana por todos os lados, no campo e nas cidades, nas capitais e no interior, nos vilarejos acanhados e nas grandes megalópoles, nos países mais e nos menos ricos. Para o que quer que se olhe, para onde quer que se vá despontam os rastros dessa vertigem lógica que continua a tanger o mundo, e de modo cada vez mais violento. Mas foi você quem disse que ${ }^{5}$ a burguesia não pode existir sem revolucionar continuamente os instrumentos de produção, que o revolucionamento contínuo da produção, o abalo ininterrupto de todas as situações sociais, a insegurança e a movimentação eternas distinguem a época burguesa de todas as outras, que todas

\footnotetext{
${ }^{3}$ Vide declaração do famoso físico Stephen Hawking em entrevista concedida em 2014 sobre a possibilidade de a Inteligência artificial destruir a humanidade. Disponível em: https://www.bbc.com/portuguese/noticias/2014/12/141202_hawking_inteligencia_pai.

${ }^{4}$ A máxima decorre das considerações de Hegel sobre possibilidade e efetividade na Ciência da Lógica, em particular na Doutrina da Essência. Ver a esse respeito também Fausto (1987), ensaio 2.

${ }^{5}$ Daqui até o final desse período, copio frases do próprio Marx no manifesto comunista na tradução de Marcos Mazzari publicada no número 12, volume 34 (1998) da revista Estudos Avançados do IEA-USP.
} 
as relações fixas e enferrujadas, com o seu séquito de veneráveis representações e concepções, são dissolvidas, que todas as relações novas, posteriormente formadas, envelhecem antes que possam enrijecer-se, que tudo o que está estratificado e em vigor volatilizase, que todo o sagrado é profanado, enfim, que a burguesia cria para si um mundo à sua própria imagem, que ela configura de maneira cosmopolita a produção e o consumo de todos os países, que através das comunicações infinitamente facilitadas, a burguesia arrasta todas as nações, mesmo as mais bárbaras, para dentro da civilização (isto é da sociedade burguesa).

Pois então, esse mundo novo e quase irreconhecível é a objetivação dessa incrível profecia que você fez. São Paulo, por exemplo, a cidade onde moro, com seus quase 12 milhões de habitantes, seus 4,5 milhões de veículos nas ruas, sua permanente e sufocante poluição, sua vida agitada e barulhenta, suas centenas de milhares de estabelecimentos comerciais, sua indústria, seus serviços e o coração do sistema bancário e financeiro nacional é a capital econômica do Brasil. Quando a cidade completou 450 anos, em 2004, eu publiquei um artigo no jornal de maior circulação no país, a Folha de São Paulo, para tentar decifrar essa espécie de esfinge na qual ela se transformou. ${ }^{6}$ Nele eu cito você e tento copiar meio descaradamente seus modos de expressão. Vou reproduzir alguns trechos para te dar uma ideia do tamanho do seu acerto.

Eu começo me fazendo a seguinte pergunta: "Por que São Paulo explodiu neste conglomerado urbano de 10,5 milhões de habitantes? São Paulo não fica no litoral nem é um paraíso de belezas naturais. A história não fez dela capital do país, nem por obra do acaso nem por obra do planejamento. Então por quê? Que força foi essa que, em pouco mais de um século, produziu uma megalópole do pequeno vilarejo interiorano, que, há mais de 300 anos, posto em sossego pelo difícil acesso, dormitava num planalto a 800 metros do nível do mar?"

6 "São Paulo, capital". Folha de São Paulo, 30 de janeiro de 2004. 
Minha resposta vai direto às descobertas que você fez: "A força que operou, para o bem e para o mal, esse milagre", continuo eu, "chama-se capital. Essa lógica, que transcende o arbítrio daqueles que a operam, revoluciona constantemente o meio em que atua. Todo e qualquer espaço deixado inteiramente sob seu domínio tornase um ambiente de mudança contínua, de abalos e transformações ininterruptas. O café, depois a indústria, agora os serviços fizeram da 'pequena São Paulo calma e serena'7 (...) esse cenário vertiginoso, que tonteia os visitantes menos avisados. São Paulo é a objetivação do capital periférico, em sua concretude contraditória de riqueza suntuosa e de pobreza aviltante, de civilização e de barbárie".

O último período do texto faz referência evidente à chamada lei geral, que você enuncia no capítulo 23 do livro I de sua obra magna. Ali você diz que o acúmulo de capital e riqueza num polo, se dando em simultâneo ao acúmulo de miséria, ignorância e degradação moral no polo oposto, é a lei geral da acumulação capitalista. Este é outro de seus grandes acertos. Essa lei vigorou ao longo de todo esse tempo, desde que você partiu, e continua hoje vivíssima, mais forte do que nunca. "Mas, esse furor que leva tudo de roldão", eu digo lá no meu artigo sobre São Paulo, "é a forma dita civilizada de produzir os chamados meios de vida. As levas humanas que a cidade foi atraindo ao longo de sua história recente vieram todas, indistintamente, atrás dessa oferta, que sempre pareceu por aqui abundante. Decorre daí seu tão decantado ecumenismo social, sua capacidade de conter em si raças, línguas, credos e costumes os mais diversos".

O Brasil é formado por levas de imigrantes, a começar pelos portugueses, seus "descobridores", seguidos pelos escravos negros, necessários para trabalhar nas plantations e na lida doméstica das casas portuguesas, seguidos por fim por todo um contingente de imigrantes de todas as partes do globo, cuja vinda os sucessivos governos brasileiros foram cuidando de incentivar depois que o país,

\footnotetext{
${ }^{7}$ Me aproprio aqui de verso da conhecida canção “Lampião de Gás”, de Zica Bergami e Hervê Cordovil, que fez enorme sucesso, no início dos anos 1960, na voz de Inesita Barroso.
} 
empurrado pelo espírito de época do final do século XIX, foi obrigado a abolir a escravidão (foi o último país a fazer isso, é bom que se diga). São Paulo, a maior cidade do Brasil, localizada no Sudeste, é essa história condensada e espessada pela força que o capital ganhou por aqui. Nesta Pauliceia Desvairada, como a chamou um grande poeta paulistano, mais do que em qualquer outra parte do país, essa história anda pelas ruas. Assim como anda também, de braços dados com a desigualdade superlativa do capitalismo periférico que gosta de morar na Pauliceia, nossa desigualdade regional - brasileiros nordestinos e nortistas que passaram a chegar por aqui às centenas de milhares todos os anos, na esperança de vida melhor.

"Mas", eu continuo, e agora você aparece explicitamente "já faz algum tempo que a cidade perdeu essa capacidade [de produzir meios de vida para tantos quantos aqui chegassem]. Marx diz que o homem moderno, privado de meios de vida, é um indivíduo abstrato (...) Desprovido de meios de vida, ou seja, de propriedade e de dinheiro, o indivíduo é concretamente, e miseravelmente, abstrato. A autonomia e a independência que ele aparenta revelam aí dolorosamente a ilusão em que se constituem. Ele não é dono e senhor de seu destino, não arbitra sobre a condução de sua vida, apenas sobrevive, e mal, quando consegue". E concluo dizendo que "São Paulo é hoje uma grande usina de produção de indivíduos abstratos", que "a 'generosidade' capitalista da cidade perdeu o fôlego" e que "o vendaval neoliberal que, há mais de uma década, tomou de assalto as periferias capitalistas empilha aqui suas vitórias, ${ }^{8}$ mais do que em qualquer outro lugar do país".

\footnotetext{
${ }^{8}$ No jornal não tinha como fazer a referência, mas aqui aproveito para homenagear o grande mestre Roberto Schwarz e sua estupenda escrita. A expressão é dele no magnífico ensaio "Fim de Século", que encontra-se em Sequências Brasileiras, de 1999. Falando dos desencontros entre Economia e Nação produzidos pela nova realidade do capitalismo, tema que não é estranho ao de nossa conversa com Marx até aqui, antes o contrário, mas tendo seu foco sobre a cultura, Schwarz diz: “Essa estetização consumista das aspirações à comunidade nacional não deixa de ser um índice da nova situação também da... estética. Enfim, o capitalismo continua empilhando vitórias." (p. 162)
} 
A atuação combinada do ímpeto transformador da sociedade burguesa, que você detectou, com a lei geral da acumulação capitalista, que você enunciou, faz com que esse mundo contemporâneo brilhante e estridente, acelerado e vertiginoso, em conjunto com seu apêndice paralelo e imagético seja também anti-humano e hostil à natureza. São Paulo é só um dentre tantos exemplos que poderiam ser listados para demonstrar o resultado desse movimento. Apesar do extraordinário crescimento material a partir daí gerado, tal movimento não produz o desenvolvimento do espírito humano, mas sua ruína. Basta um passeio rápido pelas periferias empobrecidas e violentas de São Paulo para nos darmos conta disso.

Mas graças às contingências da História, essa brutalidade sistêmica foi por algum tempo domesticada e produziu, ao menos no centro do capitalismo, uma sociedade menos desequilibrada, em que também os trabalhadores se beneficiaram minimamente dos avanços materiais e da riqueza produzida. Por essa época, era comum ouvir críticas contumazes à sua lei geral do capitalismo, pois, afinal, o sistema ia melhorando e facilitando a vida de todos, pobres e ricos, trabalhadores e capitalistas e com uma redução significativa da desigualdade entre as classes sociais e as faixas de renda; em poucas palavras, a realidade do capitalismo (de alguns poucos países) na segunda metade do século XX estaria desmentindo essa lei. Houve até um filósofo alemão, pensador de grande peso, de "quatro costados", como se diz aqui na minha terra, que, tendo sido criado intelectualmente numa escola que teve você e sua teoria como inspiração, passou a criticá-lo, pelo suposto caráter estreito de sua visão materialista. Segundo ele, Jürgen Habermas, como você teria dado primazia ao trabalho, ao invés de à linguagem no processo de posição do homem na História, teria ficado preso à razão centrada no sujeito, típica do racionalismo ocidental, sem perceber a importância e mesmo a possível prevalência da razão comunicacional, de fundamento intersubjetivo. Ele estando certo, a sociedade moderna ocidental caminharia cada vez mais nesse sentido, impedindo a existência de um mundo onde a miséria, a indigência 
e a ignorância, em uma palavra, o aviltamento do espírito humano, ofuscasse e questionasse o substantivo desenvolvimento material.

Habermas escreve o livro onde enuncia essa tese no início da década de $1980,{ }^{9}$ quando a destruição daquele capitalismo domesticado estava ainda em seu início e tudo parecia conspirar, ao menos no mundo desenvolvido de onde falava nosso filósofo, para o crescente predomínio da esfera pública, com sua comunicação sem coerção e suas virtudes derivadas das relações no "mundo da vida" frente à racionalidade instrumental dura e insensível do sistema do poder e do sistema do capital. Como parecia que as limitações materiais iam sendo superadas (ao menos em alguns poucos países, repito) pelo próprio desenvolvimento capitalista (que não estaria assim comprovando sua lei geral), parecia também que a razão intersubjetiva é que teria traçado o fio condutor da História, e não a razão subjetiva, condutora da vida material e da atividade do trabalho. ${ }^{10}$

A tese acabou por fazer coro com todo um conjunto de outras visões igualmente contestadoras da razão de fundamento subjetivo e assentadas nessa sorte de linguistic turn que poderíamos reunir sob o título de pós-modernismo, as quais surgiram mais ou menos pela mesma época. Mas enquanto Habermas procura, com sua defesa da razão comunicacional, salvar os fundamentos da Modernidade, atuando afinal ainda como um iluminista (como você também é), os filósofos e correntes pós-modernas - desconstrucionistas, ${ }^{11}$ pragmáticos ${ }^{12}$

${ }_{9}^{9}$ Refiro-me à Theorie des Kommunikativen Handelns (Teoria do Agir Comunicativo), publicada pela primeira vez em 1981.

${ }^{10}$ Para uma boa crítica de fundamentação materialista à tese habermasiana, ver Haddad (2004, ensaio 1).

${ }^{11}$ A referência evidente é à filosofia desconstrucionista de Jacques Derrida. Em seu $O$ Discurso Filosófico da Modernidade, o próprio Habermas faz uma boa apreciação crítica, do ponto de vista da defesa da Modernidade, do desconstrucionismo de Derrida (2000, capítulo VII).

${ }^{12}$ Refiro-me aqui, principalmente à filosofia relativista de Richard Rorty. Vide Rorty (1994). 
retóricos, ${ }^{13}$ relativistas de modo geral - vão jogar no time contrário, o da razão indeterminada. Em sua ambiguidade constitutiva, o pósmodernismo parece desafiar a ordem social com sua pregação pela nãoidentidade, pela transgressão, pelo relativismo, pela desconstrução; mas como a sociedade organizada pelo mercado precisa desse espírito anárquico, sendo de certa forma sua própria objetivação social, toda essa contestação acaba servindo afinal para afirmar e alimentar essa ordem social, ao invés de refutá-la. ${ }^{14}$

Mas me perdi aqui nos meus devaneios e acabei adentrando a seara da Filosofia. Vamos mudar de rota e falar um pouco daquilo que também me interessa nesta missiva, que é pô-lo a par dos caminhos e descaminhos da Economia Política, desde que você construiu sua magnífica crítica e criou um paradigma teórico novo, que leva seu nome.

Não sei se você teve conhecimento de que, no início da década de 1870, surgiram três livros que promoveram várias alterações na velha Economia Política que você criticou. ${ }^{15}$ Em 1871, o inglês William

13 A retórica pode ser vista como um produto do relativismo. Como projeto de ciência, em particular considerando-se a Economia, foi defendida principalmente por McCloskey. Vide McCloskey (1985).

${ }^{14}$ Reproduzo aqui argumentos já desenvolvidos em Paulani, 2005, ensaio 5, os quais tomaram por base Eagleton (1998).

${ }^{15}$ Já procurei muito e por diversos meios descobrir se Marx chegou a ter conhecimento das obras de Jevons, Menger e Walras, publicadas cerca de uma década antes de sua morte. Ainda que a pesquisa não tenha sido sistemática, nunca encontrei nenhuma menção a qualquer delas nos trabalhos de Marx (ou quando encontrei estava com foco em outras questões e não registrei). Assim, a menos de engano meu, Marx nunca se referiu a elas. Minha hipótese é que as mesmas não tiveram, à época de sua publicação, a importância que vieram a ter posteriormente, justificando o porquê do silêncio de Marx. Uma boa oportunidade para fazer referência a esses autores e a sua teoria do valor-utilidade teria sido nas Glosas marginais ao Manual de Economia Politica de Adolph Wagner, que Marx redige em 1879-80, não só pelo momento em que escreve esse trabalho (quando todas as três obras já haviam sido publicadas), mas pelo tema do mesmo (uma crítica a um suposto tratado de economia). No entanto, tampouco ali encontra-se qualquer referência. No prefácio que escreve quando da publicação do Livro III de O Capital em 1894, Engels menciona Jevons e Menger. Já ao final do século, portanto, o companheiro intelectual de Marx conhecia esses dois autores. 
Stanley Jevons publicou A Teoria da Economia Politica (The Theory of Political Economy) e, no mesmo ano, o austríaco Carl Menger publicou Princípios de Economia (Grundsätze der Volkswirtschaftslehre); finalmente, em 1874, o francês León Walras publicou Elementos de Economia Política Pura (Élements d'Economie Politique Pure). Os citados volumes deram ensejo a uma assim dita "revolução marginalista" e acabaram por transformar radicalmente aquilo que passaria a ser conhecido como ciência econômica ao longo de todo o século XX. Apesar de terem cada um as suas especificidades, os três livros tinham alguns pontos em comum.

O ponto em comum mais importante era a substituição da teoria do valor-trabalho, que você criticara e desenvolvera, pela teoria do valor-utilidade. Ao invés de conferir a determinação do valor a um fundamento objetivo, o tempo de trabalho (ou os custos de produção, que remetem todos, ao fim e ao cabo, a tempo de trabalho vivo ou morto), todos eles associaram o valor à utilidade dos bens, um atributo de natureza subjetiva. E foi assim que o valor de uso, que era mero carregador do valor na Economia Política clássica (e quem deixou isso mais claro foi você), foi promovido a seu fundamento, como se a universalidade da qual carece o fundamento pudesse se resumir à infinidade de suas determinações particulares, sem ter de alcançar o singular, para usar grosseiramente a linguagem de Hegel.

A outra convergência que há, e ela não é menos importante, é que as classes sociais desapareceram de cena nessa "nova" forma de ver o mundo econômico. Trabalhadores, capitalistas e proprietários de terra tornaram-se, para os três autores, meros agentes econômicos, ora produtores, ora consumidores, sem que seus distintos papeis na reprodução material da sociedade fizesse qualquer diferença em sua dinâmica e em seus descaminhos (que para eles, aliás, não existem, pois a economia de mercado tenderia sempre ao equilíbrio). Junto com essas substantivas alterações veio também a mudança no nome da ciência. Proposta por Jevons, no prefácio à segunda edição de seu livro, publicada em 1879, ela tornou-se apenas Economics, ao invés de Political 
Economy. Segundo o próprio autor, o antigo nome era "composto e problemático", de modo que a substituição sugerida, por um termo simples, era mais "conveniente".

E com isso, meu caro Marx, aquilo que você chamou em seu tempo de "economia vulgar" tornou-se o grande e vitorioso paradigma, jogando por terra a economia política clássica original, que, a despeito de todas as suas críticas, você sempre tomou como ciência. Lembra o que você dizia de Say, Senior e tutti quanti, que eles investigavam tão somente o nexo aparente e ruminavam o material fornecido pela economia científica apenas para arrumar uma justificativa plausível dos fenômenos mais brutais e atender às necessidades da própria burguesia? ${ }^{16}$ Pois então, Jevons, Menger e Walras tomaram aquelas ideias esboçadas por Jeremy Bentham no início do século XIX, de que a motivação humana em todos os tempos e lugares pode ser reduzida ao desejo de "maximizar utilidade" e de que é a utilidade que determina o valor das mercadorias, para construir um corpo teórico "novo", que vai suplantar o velho paradigma assentado na teoria do valor-trabalho.

Com as inovações desse trio, a economia vulgar não precisou mais ruminar o material fornecido por um paradigma que já se tornara muito perigoso e pouco "conveniente", para usar os termos de Jevons. Bentham, o oráculo insipidamente pedante e fanfarrão do senso comum burguês, como você gostava de chamá-lo ${ }^{17}$ foi o responsável por lançar as sementes que vieram a frutificar no final do século XIX. Menos de duas décadas mais tarde, outro inglês, Alfred Marshall, se encarregaria de colocar todas essas novas ideias num livro de tipo "manual", que até hoje fornece a base dos livros texto utilizados nos cursos superiores de economia mundo afora, o que permitiu a afirmação cada vez maior do novo paradigma, tornando-o dominante. ${ }^{18}$

\footnotetext{
${ }^{16} \operatorname{MARX}(2013$ [1967], p. 156).

${ }^{17}$ Idem (p. 684).

18 Para uma análise fundamentada da importância de Marshall nesse processo de afirmação do novo paradigma, veja-se Mattos (2010).
} 
Ao final do Livro III de O Capital, comentando a fórmula trinitária (trabalho-salário, capital-lucro, terra-renda), você disse que a economia vulgar não é nada além de uma tradução didáticodoutrinária das concepções correntes dos agentes reais da produção (ou seja, das configurações da aparência), nas quais ela introduz uma certa ordem inteligível, que torna confortáveis esses mesmos agentes e que se põe muito ao gosto das classes dominantes. ${ }^{19}$ Pois a tal "revolução marginalista" mudou um pouco esse panorama. Apesar de fazer jus à sua herança "intelectual", continuando a deter a preferência de dez entre dez membros da burguesia e operadores dos mercados, a nova visão, mesmo já tratada pela alquimia marshalliana, mostrou-se, na verdade, muito pouco intuitiva, com ideias difíceis de engolir (a começar, aliás, pela própria ideia de utilidade marginal). $\mathrm{O}$ irrealismo dos pressupostos de tal paradigma é tão marcado que deu origem, em meados do século XX, a um famoso debate metodológico, no qual despontou, fazendo sua defesa, o economista americano Milton Friedman ${ }^{20}$ - um personagem sobre o qual você talvez dissesse, se tivesse tido a oportunidade de conhecer os seus trabalhos, a mesma coisa que dizia sobre Bentham: "um gênio da estupidez burguesa". ${ }^{21}$

À parte as ideias excêntricas presentes nos manuais (a existência de concorrência perfeita entre infinitas empresas e o lucro normal sendo zero, são algumas dessas preciosidades), o andamento das pesquisas teóricas no paradigma que passou a vigorar levou a um resultado ainda mais bizarro: a existência de um mundo em que fica comprovado matematicamente o equilíbrio geral que Walras tentara demonstrar, mas que tem um pequeno problema com a realidade de fato existente:

\footnotetext{
${ }^{19} \operatorname{MARX}$ (2017 [1894], p. 893).

${ }^{20}$ O debate se deu a partir da publicação, em 1953, do conhecido artigo de Milton Friedman, The Methodology of Positive Economics. Paul Samuelson e depois Fritz MachLup entraram na discussão, dentre outros. Para uma apreciação do debate vejase Hands (2001).
}

${ }^{21} \operatorname{MARX}(2013$ [1867], p. 685). 
nele não há lugar lógico para o dinheiro. ${ }^{22}$ Todas as tentativas de se encontrar um lugar para o dinheiro nesse mundo foram frustradas. Numa delas, por exemplo, quando se consegue inseri-lo nesse mundo mágico, onde o equilíbrio geral existe, ele aparece com preço zero, ou seja, como um bem livre. ${ }^{23}$ Faz algum sentido, qualquer que ele seja, um dinheiro que é um bem livre? Imagino o que você diria de um tal "modelo".

Pois então, essa é a Economics hoje vigente. A pergunta sobre por que uma coisa tão estapafúrdia continua a vigorar como ciência, você mesmo respondeu, no início da mesma década de 1870 em que surgiram os rebentos "revolucionários" da economia vulgar. No posfácio à segunda edição do Livro I de $O$ Capital, que você escreve em 1873, você decreta a sentença de morte da economia científica burguesa. ${ }^{24}$ Para você, depois que a burguesia tinha conquistado o poder político na Inglaterra ena França, a luta de classes tinha assumido formas cada vez mais explícitas, como o demonstrara o vulcão social de 1848, desmantelando assim, também no plano fenomênico, a ideia de uma sociedade de iguais, de um mundo sem privilégios, onde todos se beneficiavam das virtudes que a providência do mercado garantia. O caráter de classe da nova sociedade que nascera no Ocidente tinha sido escancarado pela História e não podia mais ser ignorado. Você observa também que os verdadeiros economistas políticos, como John Stuart Mill, ainda tentaram, num esforço desesperado, sintonizar a Economia Política do capital com as reivindicações não mais ignoráveis das massas trabalhadoras. Mas isso mostrou-se impossível porque o sino fúnebre daquela ciência, já tinha soado. Não se tratava mais então, diz você, de saber se este ou aquele teorema é ou não verdadeiro, mas se, para o capital, ele é útil ou prejudicial, cômodo ou incômodo. Com

\footnotetext{
22 Ver a respeito Hahn (1984).

${ }^{23}$ A tentativa é de Patinkin (1956), a partir do modelo de Kenneth Arrow e Gerárd Debreu (1954). Reproduzo aqui argumentos de minha tese de doutorado (1992), baseados, entre outras, na análise de Hahn (1984).
}

${ }^{24} \operatorname{MARX}(2013$ [1867], p. 86). 
seu estilo ferino, você diz que, no lugar da pesquisa desinteressada entrou a soldadesca mercenária e no lugar da pesquisa científica imparcial entrou a má consciência e a má intenção da apologética. ${ }^{25}$ Então, você acertou em cheio, mais uma vez, pois essa é a única explicação que pode haver para o continuado domínio do paradigma assentado na teoria do valor-utilidade no mundo da ciência econômica (que, enquanto ciência tem, naturalmente uma pretensão à verdade). Mas aconteceu ainda mais uma volta nesse parafuso.

Lembra que mencionei um período em que o capitalismo foi domesticado, parecendo jogar por terra sua lei geral? Pois então, ele foi fruto de um período conturbadíssimo da História, em que houve duas guerras mundiais e uma enorme depressão econômica entre elas. $\mathrm{O}$ processo de centralização de capitais, que você descreveu no capítulo 22 do Livro I, foi dando origem àquilo que alguns autores inspirados por você passaram a chamar de imperialismo. ${ }^{26} \mathrm{~A}$ guerra por territórios que se intensifica no início do século $X X$ por força da necessidade capitalista de encontrar redenção para um pletora sempre crescente de capitais excedentes é uma guerra moderna, um imperialismo burguês, vitaminado pela ideia de "formação nacional", que se fortalecera, também ela, como uma exigência do capital. ${ }^{27}$ No ínterim entre as duas guerras interimperialistas, de 1914-18 e de 1939-45, o capitalismo experimentou uma imensa retração em suas taxas de crescimento, que levou 10 anos para reverter (e que segundo alguns só acabou mesmo com o advento da própria segunda guerra).

A partir de 1929 (o início da grande depressão), as taxas de desemprego elevaram-se a níveis alarmantes, chegando a mais de $20 \%$ nos Estados Unidos e no Reino Unido. A teoria convencional, baseada no tal "novo" paradigma, herdeiro da economia vulgar de seu tempo, só tinha para esse fenômeno uma explicação tão bisonha quanto

\footnotetext{
${ }^{25}$ Retomo nesses últimos períodos considerações já feitas em Paulani (2010).

${ }^{26}$ Refiro-me a Hobson e a Lenin.

${ }^{27}$ Abraço aqui as teses de Harvey (2004).
} 
implausível: o desemprego era, para os epígonos daquele tempo (Arthur C. Pigou em destaque), um fenômeno derivado apenas e tão somente dos desejos do próprios trabalhadores. Sua tese era que, se os trabalhadores se dispusessem a trabalhar por qualquer salário oferecido no mercado, sempre haveria um salário capaz de empregar toda a mão de obra. Em outras palavras, eles diziam que todo desemprego, por elevado que fosse, devia ser considerado, sempre, como "desemprego voluntário".

Era tão evidente a incapacidade da teoria dominante de enfrentar o fenômeno iniciado em 1929 que provocou a revolta de um dos mais diletos e nobres filhos dessa tradição. John Maynard Keynes, discípulo de Marshall, filho de John Neville Keynes, também ele economista importante da honorável Universidade de Cambridge (o berço de Marshall), escreve, em 1936, um livro que tece críticas destruidoras a essa visão, então impropriamente chamada de "clássica". Para ele, ao contrário do que o paradigma vigente supunha, a economia não estava sempre no pleno emprego de seus recursos, nem tendia naturalmente para ele. Ele vai mostrar quehá momentos em que, movida por sua própria lógica, a economia capitalista passa a operar num nível muito abaixo desse pleno emprego, produzindo crises sociais severas como a que o mundo desenvolvido estava então experimentando. Sugeria então que algum elemento não submetido a essa lógica entrasse em cena para reerguer a economia e mantê-la operando num nível mais elevado e melhor para todos, e esse elemento era o Estado.

O paradigma keynesiano foi assimilado pela economia convencional, gerando o que passou a ser conhecido como "síntese neoclássica". ${ }^{28}$ Fora dos muros da academia, o keynesianismo teve enorme repercussão prática, gerando, por décadas, alterações substantivas na política econômica de vários países. Foi pelas mãos

\footnotetext{
${ }^{28}$ Até onde se sabe, o termo foi cunhado por Paul Samuelson, um dos teóricos que, a partir do trabalho seminal de John Hicks "Mr. Keynes and the Classics: A Suggested interpretation", publicado na revista Econometrica, em 1937, ajudou a desenvolver esse formato bem comportado da visão keynesiana.
}

cadernos cemarx, $\mathrm{n}^{\mathrm{o}} 11-2018$ 
do keynesianismo que o capitalismo se domesticou e gerou o período, conhecido hoje como "os trinta anos gloriosos do capitalismo" do final da segunda grande guerra (1945) até o início dos anos 1970 que parecia ter deitado por terra sua lei geral.

Uma crise de sobreacumulação combinada a um problema gerado pelo dinheiro mundial de então, o dólar americano, acabou com a era keynesiana e fez retornar a força das finanças (daquilo que você chama capital portador de juros em conjunto com seu sucedâneo, o capital fictício), que havia ficado relativamente controlada no período anterior. Daí porque, para muitos dos economistas que ainda seguem a tradição que você inaugurou, o mundo vive hoje um capitalismo "financeirizado", em que a lógica rentista e curto-prazista do capital portador de juros se sobrepõe à lógica do capital em funções, ou seja, aquele aplicado na produção de bens e serviços. Há uma enorme polêmica sobre isso, um enorme debate e muita produção acadêmica, que não tenho aqui espaço para te apresentar. Mas o que eu quero te contar, para terminar esta já bem longa carta, tem que ver com o outro lado da história, com o que aconteceu na academia, a última volta do parafuso.

Ao final dos anos 1960, o economista americano Robert Lucas publica um artigo baseado na assim chamada "teoria das expectativas racionais" para demonstrar (contra Keynes) que a atuação do Estado tenderia a ser sempre inócua, uma vez que os agentes conheceriam sempre o modelo de atuação do governo, conseguindo antecipar suas políticas e suas ações. Assim, por exemplo, se o governo faz um gasto contracíclico para azeitar a dinâmica econômica num momento de retração ou redução das taxas de crescimento, os agentes já preveem por isso um aumento de tributos mais à frente e contraem de imediato sua atividade, anulando, assim, o efeito pretendido pelo governo. Os conturbados anos 1970, com aprofundamento da crise, desemprego e inflação em alta mundo afora, e questionamento constante das conquistas dos "30 gloriosos", ofereceram o habitat ideal para o crescente sucesso da teoria das expectativas racionais e a derrocada das ideias e princípios keynesianos. 
Sua maior crítica, Marx, aos clássicos do pensamento econômico, Smith e Ricardo, foi à naturalização que eles acabavam propondo das ideias e da realidade de seu próprio mundo como se fossem a batida monocórdica da História, como se sempre tivesse sido assim, como se fosse natural aquilo que é social e historicamente construído: o modo de produção capitalista. Na introdução que você escreveu para a Contribuição à Crítica da Economia Política (e não publicou), você disse que os profetas do século XVIII, sobre cujos ombros se apoiaram diretamente Smith e Ricardo, viram o indivíduo do século XVIII não como resultado histórico, mas como ponto de partida da História, como se ele tivesse sido posto como tal pela natureza. Pois os nossos "profetas" da extravagante teoria das expectativas racionais foram ainda mais longe: puseram a si mesmos como modelo da racionalidade humana. Thomas Sargent, um dos expoentes da nova teoria, disse numa entrevista que estava ciente dos problemas existentes com os supostos das expectativas racionais, que sabe das contradições filosóficas sobre seu uso e que, no fundo, não acredita inteiramente neles, mas que continua a utilizá-los. ${ }^{29}$

Assim, se ainda era possível falar da ideologia como falsa consciência nos bons tempos da economia política clássica, nesta vida post mortem da economia "científica", talvez só possamos mesmo falar de uma sorte de "falsa consciência esclarecida", do cinismo como única "razão" capaz de estabilizar um sistema em que os valores e critérios normativos supostamente trazidos pelo mundo "civilizado" estão se decompondo. ${ }^{30}$ Parece-me, caro Marx, e não só a mim, que o capitalismo entrou numa nova fase, em que dispensa os adereços que teve de utilizar um dia (liberdade, igualdade, direitos individuais, democracia) e aos quais Keynes, visando, em benefício da sobrevivência do sistema, evitar os precipícios sociais que marcaram a primeira metade do século XX, acrescentou alguns outros (pleno emprego,

${ }^{29}$ Entrevista concedida a Arjo Klamer e presente no livro Conversas com Economistas. ${ }^{30} \mathrm{Me}$ apoio aqui nas considerações de Safatle (2008). 
finanças sob controle). Reinando a quase três décadas absoluto e inconteste (de 1917 até o final dos anos 1980 ele teve que enfrentar um outro sistema, produzido por uma revolução deflagrada a partir dos seus ensinamentos, mas isso é outra história), o capitalismo, como você previu, arrastou para seu mundo todas as nações e fez do planeta uma grande e única plataforma de produção. Manipulada por corporações gigantes, essa plataforma dispõe de um exército industrial de reserva global que reduz a muito pouco o poder dos trabalhadores, porque esfacela o poder local dos sindicatos. Infelizmente, contra aquilo que você pregou, foi o capital, e não a luta contra o sistema, que promoveu essa (funesta) união dos trabalhadores do mundo. O capital financeiro no exercício pleno de seu poder, um dinheiro mundial inconversível e o mundo virtual e imagético do qual falei anteriormente têm tudo a ver com essa história de "sucesso" do sistema do ponto de vista do capital, e de desastre do ponto de vista social e ambiental (ninguém sabe quanto tempo mais o planeta aguenta o ritmo do capital).

Esse "sucesso" tem consequências muito mais profundas do que aquelas que podem ser percebidas no plano puro e simples da acumulação. A lógica e os princípios da gestão empresarial e da concorrência de mercado vão invadindo todas as esferas da vida e impondo sua "nova razão" ao mundo. ${ }^{31}$ Assim, por mais que as crises se sucedam de forma cada vez mais violenta (tivemos uma gigante em 2008/2009, cujas consequências estão até hoje presentes), o sistema tem sido extremamente bem sucedido na sua capacidade de repetir os rituais materiais que afirmam a ideologia na esfera do fazer (e não do saber). Nesse contexto, a razão cínica, por afirmar a distância entre os princípios proclamados e a prática que a eles se refere, põe a contradição, mas ao mesmo tempo a resolve. Com isso, nem todos os problemas se acabam para o capital, porque as aspirações de legalidade (critérios normativos, valores partilhados) não desaparecem de uma hora para

${ }^{31}$ Claramente me refiro aqui às teses de Pierra Dardot e Christian Lavall (2016), com as quais concordo. 
outra. A obsolescência do desmascaramento ideológico indica apenas que as promessas de modernização e de racionalização da realidade social já foram realizadas pelo capitalismo, de forma cínica. ${ }^{32}$

Bom, misturei um monte de coisas aqui, falei tudo embolado. Talvez não fique muito claro, porque tem muito assunto aí condensado, assunto para várias cartas. Mas paro por aqui porque já devo ter te cansado.
Abração aí,
Leda Paulani

P.S.: Esqueci de te dizer: sabe a renda, aquela forma assumida pela mais valia, que você discute na última seção do último livro do Capital, e contra a qual Ricardo brigou a mais não poder por julgá-la um pecado contra a acumulação? Pois então, parece que ela está se tornando a alma do capitalismo nesse novo estágio. Mas também isso é matéria longa que demandaria outra carta. Fica aí só pra você pensar. ${ }^{33}$

\footnotetext{
${ }^{32}$ Neste último período me apropriei inteiramente das considerações de Safatle, 2016, p. 69.

${ }^{33} \mathrm{O}$ desenvolvimento desta proposição está em Paulani, 2016.
} 


\section{Referências bibliográficas}

DARDOT, P. e LAVAL, C. A Nova Razão do Mundo - Ensaio sobre a Sociedade Neoliberal. São Paulo: Boitempo, 2016.

EAGLETON, T. As Ilusões do Pós-Modernismo. São Paulo: Jorge Zahar, 1998.

FAUSTO, R. Marx: Lógica \& Política - Volume II. São Paulo: Brasiliense, 1987.

HABERMAS, J. The Theory of Communicativ Action. Boston: Bacon Press, 1984.

HABERMAS, J. O Discurso Filosófico da Modernidade. São Paulo: Martins Fontes, 2000.

HADDAD, F. Trabalho e Linguagem para a Renovação do Socialismo. Rio de Janeiro: Azougue Editorial, 2004.

HAHN, F. Equilibrium and Macroeconomics. Oxford: Basil Blackwell Publisher Ltd., 1984.

HANDS, D. W. Reflections Without Rules. Cambridge: Cambridge University Press, 2001.

HARVEY, D. O Novo Imperialismo. São Paulo: Loyola, 2004.

HEGEL, G. W. F. Ciência da Lógica - Vol. II. Petrópolis: Vozes, 2017 [1813].

124 A economia política hoje (e outros assuntos) 
KEYNES, J. M. The General Theory of Employment, Interest and Money. New York: Harcourt, Harbinger, 1983 [1936].

KLAMER, A. (Org.) Conversas com Economistas. São Paulo: Edusp/ Pioneira, 1988.

McCLOSKEY, D. The Rethoric of Economics. Madison: The University of Viscousin Press, 1985.

MARX, K. Manifesto do Partido Comunista. Estudos Avançados, vol. 12, no 34, 1998 [1848].

MARX, K. Para a Crítica da Economia Política. In: Marx (coleção Os Pensadores). São Paulo: Abril Cultural, 1978 [1859].

MARX, K. O Capital, volume I. São Paulo: Boitempo, 2013 [1867].

MARX, K. O Capital, volume II. São Paulo: Boitempo, 2014 [1867].

MARX, K. O Capital, volume III. São Paulo: Boitempo, 2017 [1894].

MATTOS, L. V. Marshall e os Críticos à Economia Política Clássica. Revista de Economia Política, volume 30, nº 2, 2010.

PAULANI, L. M. Do Conceito de Dinheiro e do Dinheiro como Conceito. Tese de doutorado. Instituto de Pesquisas Econômicas, Universidade de São Paulo (IPE-USP), 1992.

PAULANI, L.M. Modernidadee Discurso Econômico. São Paulo, Boitempo, 2005. 
PAULANI, L. M. Ciência Econômica e Modelos de Explicação Científica: retomando a questão. Revista de Economia Política, volume 30, nº $1,2010$.

PAULANI, L. M. Acumulação e Rentismo: resgatando a teoria da renda de Marx para pensar o capitalismo contemporâneo. Revista de Economia Política, vol. 36, nํㅜ 3, 2016.

PATINKIN, D. Money, Interest and Prices - an Integration of Monetary and Value Theory. Cambridge: Mass, the MIT Press, 1989 [1956].

RORTY, R. A Filosofia e o Espelho da Natureza. Rio de Janeiro: RelumeDumará, 1994.

SAFATLE, V. Cinismo e Falência da Crítica. São Paulo, Boitempo, 2008.

SCHWARZ, R. Sequências Brasileiras. São Paulo: Companhia das Letras, 1999. 